\title{
HAK PATEN PADA PRODUK SONY SERTA PENGAJUAN KLAIM DARI SUATU PENEMUAN (INVENSI)
}

\section{FIRDIA RIANI}

155100033

Fakultas Komputer, 448757157

Firdiariani.student@umitra.ac.id

\begin{abstract}
Kata paten, diambil dari bahasa Inggris yaitu patent, yang awalnya berasal dari kata patere yang artinya membuka diri (untuk pemeriksaan publik), dan juga berasal dari istilah letters patent, yaitu surat keputusan yang dikeluarkan kerajaan yang memberikan hak eksklusif kepada individu dan pelaku bisnis tertentu.

Definisi kata paten itu sendiri, konsep paten mendorong inventor untuk membuka pengetahuan demi kemajuan masyarakat dan sebagai gantinya, inventor mendapat hak eksklusif selama periode tertentu. Mengingat pemberian paten tidak mengatur siapa yang harus melakukan invensi yang dipatenkan, sistem paten tidak dianggap sebagai hak monopoli. Pemberian hak paten bersifat teritorial, yaitu, mengikat hanya dalam lokasi tertentu. Dengan demikian, untuk mendapatkan perlindungan paten di beberapa negara atau wilayah, seseorang harus mengajukan aplikasi paten di masingmasing negara atau wilayah tersebut. Untuk wilayah Eropa, seseorang dapat mengajukan satu aplikasi paten ke Kantor Paten Eropa, yang jika sukses, sang pengaju aplikasi akan mendapatkan multiple paten (hingga 36 paten, masing-masing untuk setiap negara di Eropa), bukannya satu paten yang berlaku di seluruh wilayah Eropa.
\end{abstract}

Hak atas Kekayaan Intelektual (HaKI) penting untuk mengukuhkan penemuan para dosen. Salah satu perlindungan Hak atas Kekayaan Intelektual adalah mematenkan hasil penemuan. Di masyarakat umum mengartikan HaKI dan Paten dipahami sebagai istilah yang sama.

Kata Kunci : Hak atas Kekayaan Intelektual (HAKI),Pengajuan penemuan,Hak Paten. 


\section{A. INTRODUCTION}

Hak Paten, atau lebih sering disebut paten adalah hak eksklusif yang diberikan oleh Negara, dalam hal ini, Pemerintah Republik Indonesia, kepada investor atas hasil penemuannya di bidang teknologi, yang selama waktu tertentu melaksanakan sendiri penemuan tersebut atau memberikan persetujuan kepada pihak lain untuk melaksanakannya (UU 14 tahun 2001, pasal.1, ayat.1)

\section{Definis Paten}

Kata Paten, diambil dari bahasa Inggris yaitu patent, yang awalnya berasal dari kata patere yang artinya membuka diri (untuk pemeriksaan publik), dan juga berasal dari istilah letters patent, yaitu surat keputusan yang dikeluarkan kerajaan yang memberikan hak eksklusif kepada individu dan pelaku bisnis tertentu.

Definisi kata paten itu sendiri, konsep paten mendorong inventor untuk membuka pengetahuan demi kemajuan masyarakat dan sebagai gantinya, inventor mendapat hak eksklusif selama periode tertentu. Mengingat pemberian paten tidak mengatur siapa yang harus melakukan invensi yang dipatenkan, sistem paten tidak dianggap sebagai hak monopoli.

\section{Apa yang dimaksud dengan inventor?}

Inventor adalah seseorang yang secara sendiri atau beberapa orang yang secara bersama-sama melaksanakan ide yang dituangkan kedalam kegiatan yang menghasilkan invensi.

Pemilik karya intelektual disebut dengan istilah inventor. Inventor bisa dilakukan secara individu maupun kelompok. Inventor lebih mudah mendapatkan hak paten atas hasil penemuan karya intelektual mereka. Sedangkan untuk diluar inventor terlebih dahulu memperoleh pengalihan hak secara tertulis dari sang inventor.

Apabila pihak lain yang memperoleh pengalihan hak dari inventor akan 
memiliki hak paten Selama 20 tahun dari hari pertama tanggal penerimaan.

Sisanya, setelah 20 tahun hak ekslusif tersebut akan menjadi public domain. Public domain diperuntukan untuk masyarakat umum, tentu saja tetap melakukan proses ijin pada pemegang hak paten.

\section{Pemegang Paten}

Pemegang Paten adalah inventor sebagai pemilik paten atau hak paten yang menerima hak tersebut dari pemilik atau pihak lain yang menerima lebih lanjut hak paten tersebut, dan terdaftar dalam daftaran umum paten tersebut.

\section{Hak yang dimiliki oleh pemegang}

\section{Paten}

Pemegang hak paten memiliki hak eklusif untuk melaksanakan Paten yang dimilikinya dan melarang orang lain yang tanpa persetujuannya :

a.Dalam hal Paten Produk : membuat, menjual, mengimpor, menyewa, menyerahkan, memakai, menyediakan untuk di jual atau disewakan atau diserahkan produk yang di beri paten. b.Dalam hal Paten Proses: Menggunakan proses produksi yang diberi Paten untuk membuat barang dan tindakan lainnya.

-Pemegang Paten berhak memberikan lisensi kepada orang lain berdasarkan surat perjanjian lisensi.

-Pemegang Paten berhak menggugat ganti rugi melalui pengadilan negeri setempat, kepada siapapun, yang dengan sengaja dan tanpa hak melakukan perbuatan sebagaimana dimaksud dalam butir 1 di atas.

-Pemegang Paten berhak menuntut orang yang dengan sengaja dan tanpa hak melanggar hak pemegang paten dengan melakukan salah satu tindakan sebagaimana yang dimaksud dalam butir 1 di atas.

\section{Tujuan Dari Hak Paten}

Tujuan dari hak paten, yaitu:

1. Memberikan Perlindungan Hukum atas setiap karya intelektual di bidang teknologi, sehingga 
terjamin hak kepemilikan pemegang paten.

2. Mewujudkan iklim yang lebih baik bagi kegiatan invensi di bidang teknologi, sebab teknologi memiliki peranan yang sangat penting dalam pembangunan nasional secara umum dan khususnya di sektor industri

3. Memberikan insentif bagi para inventor dalam melakukan inovasi baru melalui hak eksklusif atas invensi yang dihasilkannya.

\section{Prosedur Mengajukan Permohonan} Hak Paten HaKI

Syarat mengajukan permohonan hak paten HaKI karya intelektual benarbenar terbarukan. Belum ada yang pernah mengajukan sebelumnya. Adapun cara pengecekan apakah karya kita terbarukan atau tidak. kita dapat melakukan pengecekan dokumen paten di database DJHKI dan kantor paten di luar negeri. Misalnya, pengecekan terhadap jurnal ilmiah dan sejenisnya.
Jika karya kita belum bersifat terbarukan, proses selanjutnya adalah membuat proposal pengajuan paten. Proposal pengajuan paten meliputi judul invensi, latar belakang invensi, deskripsi singkat karya intelektual yang ditemukan dan gambar teknik. Gambar teknik yang disertai dengan uraian singkat. Kemudian dilengkapi dengan abstrak dan klaim. Rangkaian inilah yang kemudian disebut dengan penyusunan spesifikasi paten.

Khusus inventor yang ditolak, diperbolehkan mengajukan banding ke Komisi Banding Paten. Nantinya, akan berlanjut ke Pengadilan Niaga dan kasasi Mahkamah Agung. Apabila inventor pengajuan hak paten tetap ditolak, maka hasil hak kekayaan intelektual akan menjadi public domain. Sedangkan untuk yang memperoleh hak paten, akan meperoleh sertifikat hak paten dari DJHKI. 


\section{Kategori Sistem Pendaftaran Paten}

- Pengajuan Permohonan Paten

Paten diberikan atas dasar permohonan dan memenuhi persyaratan administratif dan subtantif sebagaimana diatur dalam Undangundang Paten.

- Sistem Pendaftaran Paten

1. Sistem First to File, adalah suatu sistem yang memberikan hak paten bagi mereka yang mendaftar pertama atas invensi baru sesuai dengan persyaratan.

2. Sistem First to Invent, adalah suatu system yang memberikan hak paten yang menemukan inovasi pertama kali sesuai dengan persyaratan yang telah ditentukan.

- Apa yang dimaksud dengan Klaim?

Klaim adalah bagian terpentig dari suatu invensi (penemuan) yang dimintakan perlindungan, dan didalam klaim diungkapkan semua kelebihan teknik dari invensi tersebut.

\section{Hal-hal yang sebaiknya dilakukan oleh seorang Inventor sebelum mengajukan permohonan Paten}

a. Melakukan penelusuran. Tahapan ini dimaksudkan untuk mendapatkan informasi tentang teknologi terdahulu dalam bidang invensi yang sama (state of the art) yang memungkinkan adanya kaitannya dengan invensi yang akan diajukan. Melalui informasi teknologi terdahulu tersebut maka inventor dapat melihat perbedaan antara invensi yang akan diajukan permohonan Patennya dengan teknologi terdahulu.

b. Melakukan Analisis. tahapan ini dimaksudkan untuk menganalisis apakah ada ciri khusus dari invensi yang akan diajukan permohonan Patennya dibandingkan dengan Invensi terdahulu.

c. Mengambil Keputusan. Jika invensi yang dihasilkan tersebut mempunyai ciri teknis dibandingkan dengan teknologi terdahulu, maka invensi tersebut sebaiknya diajukkan permohonan Patennya.Sebaliknya jika tidak 
ditemukan ciri khusus, maka invensi tersebut sebaiknya tidak perlu diajukan untuk menghindari kerugian dari biaya pengajuan permohonan Paten.

\section{Sony Kantongi Hak Paten Lensa Kontak Pintar yang Mampu Merekam Video Hanya Dengan Kedipan}

Sony bersaing dengan Google dan Samsung yang tengah mengembangkan teknologi untuk membantu penglihatan. Tak hanya bisa memperbaiki daya lihat, lensa kontak Sony mampu merekam video hanya dengan perintah berupa kedipan mata saja. Perintah-perintah lain seperti mode on dan off bahkan pengisian daya pun dilakukan hanya dengan gerakan kelopak mata.

Ketika produsen lensa kontak lain lebih fokus pada metode perbaikan daya penglihatan atau teknologi Augmented Reality, Sony ingin selangkah lebih maju. Sebuah hak paten yang telah didapatkan pada bulan April lalu menjelaskan tentang sebuah lensa kontak yang tak hanya dapat dikontrol dengan kedipan mata si pengguna, bahkan juga dapat merekam video sesuai keinginan.

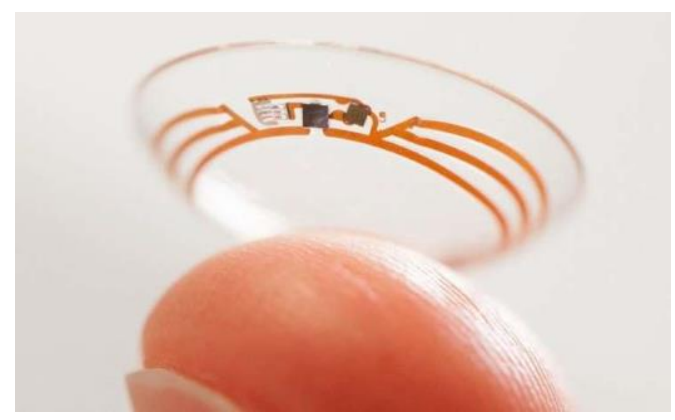

Ketika sedang dalam kondisi merekam video, lensa kontak pintar ini juga dapat mendeteksi ketika pengguna menutup mata, sehingga layar yang tidak menampilkan gambar apapun selain warna hitam itu nantinya akan dapat dihapus. Untuk memutar rekaman video, pengguna dapat melakukan gerakan tertentu yang berbeda dengan gerakan kedipan untuk mengaktifkan atau menonaktifkan mode merekam. Sensor yang disematkan pada lensa dapat membedakan antara kedipan yang sengaja dan yang tidak disengaja berdasarkan perhitungan lamanya waktu berkedip. Pengguna dapat 
mengatur mode on maupun off hanya dengan menutup kelopak mata. Selain itu, pengguna juga dapat mengontrol lensa melalui koneksi pada sebuah smartphone. Metode penangkapan gambar dan penyimpanannya akan disematkan pada lensa di sekeliling iris mata. Sebuah sensor piezoelektrik akan mengubah gerakan bola mata menjadi energi untuk menjalankan lensa. Terdengar sangat canggih sekali bukan?

Kenyataannya, saat ini teknologi yang dijelaskan di atas tak cukup kecil untuk bisa disematkan pada lensa kontak dengan nyaman, oleh karenanya bisa dikatakan teknologi ini baru sampai pada tahap teori.

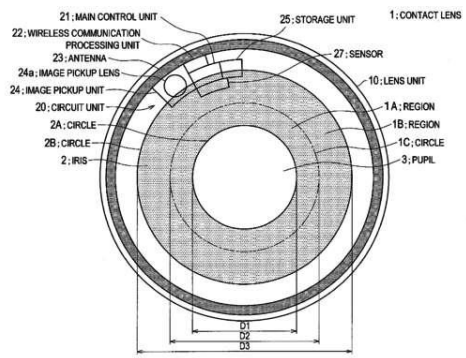

Teknologi baru yang langsung disematkan pada mata tak hanya dikembangkan oleh Sony. Google baru-baru ini juga telah mengantongi hak paten untuk sebuah lensa kontak pintar yang langsung disuntikkan atau diinjeksikan pada bola mata untuk memperbaiki daya penglihatan yang menurun. Selain Google, Samsung pun tak mau kalah dalam teknologi serupa. Bahkan, raksasa teknologi Korea Selatan ini telah mendapatkan hak paten untuk sebuah lensa kontak yang mampu mencitrakan objek langsung ke mata si pengguna. Sebuah kamera built in dan sensor yang bisa mendeteksi gerakan terpasang pada lensa kontak itu dan semuanya bisa dikontrol hanya dengan cara berkedip. Sebuah antena juga disematkan untuk menyalurkan konten kepada sebuah piranti seperti smartphone untuk mengolahnya. Bebagai penemuan baru kombinasi bidang teknologi dan kesehatan memang semakin mempermudah hidup manusia. Walaupun bukan jaminan bahwa hak paten yang telah dikantongi akan terwujud menjadi sebuah produk komersial, namun upaya dari para pengembang teknologi ini patut diapresiasi dan menjadi harapan akan munculnya sebuah produk yang dapat bermanfaat bagi banyak orang. 


\section{B. CONCLUSION}

Kesimpulan dari materi ini adalah kata paten itu sendiri, konsep paten mendorong inventor untuk membuka pengetahuan demi kemajuan masyarakat dan sebagai gantinya, inventor mendapat hak eksklusif selama periode tertentu. Mengingat pemberian paten tidak mengatur siapa yang harus melakukan invensi yang dipatenkan, sistem paten tidak dianggap sebagai hak monopoli. Pemberian hak paten bersifat teritorial, yaitu, mengikat hanya dalam lokasi tertentu. Pemilik karya intelektual disebut dengan istilah inventor. Inventor bisa dilakukan secara individu maupun kelompok. Inventor lebih mudah mendapatkan hak paten atas hasil penemuan karya intelektual mereka. Sedangkan untuk diluar inventor terlebih dahulu memperoleh pengalihan hak secara tertulis dari sang inventor.

Sony bersaing dengan Google dan Samsung yang tengah mengembangkan teknologi untuk membantu penglihatan. Tak hanya bisa memperbaiki daya lihat, lensa kontak
Sony mampu merekam video hanya dengan perintah berupa kedipan mata saja. Perintah-perintah lain seperti mode on dan off bahkan pengisian daya pun dilakukan hanya dengan gerakan kelopak mata. Teknologi baru yang langsung disematkan pada mata tak hanya dikembangkan oleh Sony. Google baru-baru ini juga telah mengantongi hak paten untuk sebuah lensa kontak pintar yang langsung disuntikkan atau diinjeksikan pada bola mata untuk memperbaiki daya penglihatan yang menurun. Selain Google, Samsung pun tak mau kalah dalam teknologi serupa.

Sony menciptakan Produk baru yang berupa Lensa Kontak Pintar yang Mampu Merekam Video Hanya Dengan Kedipan. Produk sony ini digunakan dengan bantuan Mata. Teknologi baru yang langsung disematkan pada mata tak hanya dikembangkan oleh Sony. Ketika sedang dalam kondisi merekam video, lensa kontak pintar ini juga dapat mendeteksi ketika pengguna menutup mata, sehingga layar yang tidak 
menampilkan gambar apapun selain warna hitam itu nantinya akan dapat dihapus. Untuk memutar rekaman video, pengguna dapat melakukan gerakan tertentu yang berbeda dengan gerakan kedipan untuk mengaktifkan atau menonaktifkan mode merekam.

\section{ACKNOWLEDGEMENT}

University Of Indonesia

University Of Mitra Indonesia

Telkom University

University Of Mellbourne

Saitama University 


\section{REFERENCE (Based ISO 690 )}

[1]

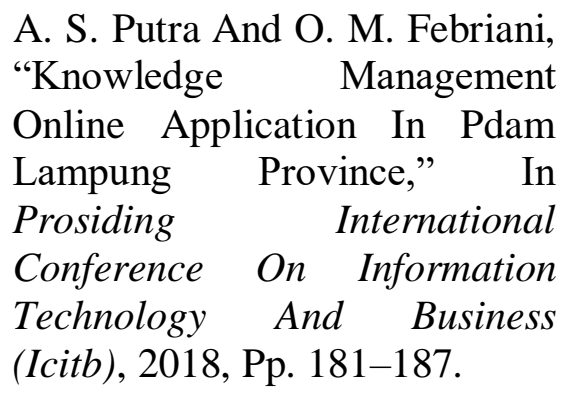

[2] A. S. Putra, O. M. Febriani, And B. Bachry, "Implementasi Genetic Fuzzy System Untuk Mengidentifikasi Hasil Curian Kendaraan Bermotor Di Polda Lampung," J. Sist. Inf. Dan Manaj. Basis Data, Vol. 1, No. 1, Pp. 21-30, 2018.

[3] O. M. Febriani And A. S. Putra, "Sistem Informasi Monitoring Inventori Barang Pada Balai Riset Standardisasi Industri Bandar Lampung," J. Inform., Vol. 13, No. 1, Pp. 90-98, 2014.

[4] Putra, Arie Setya. "2018 Artikel Struktur Data, Audit Dan Jaringan Komputer." (2018).

[5] Putra, A. S. (2018, July 17). Paperplain Fundamental Create Application With Borland Delphi 7.0 University Of Mitra Indonesia. Retrieved From Osf.Io/Pbrn9.

\section{E. REFERENCE $($ Based APA )}

Putra, A. S., Aryanti, D. R., \& Hartati, I. (2018, November). Metode SAW (Simple Additive Weighting) sebagai Sistem Pendukung Keputusan Guru Berprestasi (Studi Kasus: SMK Global Surya). In Prosiding Seminar Nasional Darmajaya (Vol. 1, No. 1, pp. 85-97).

Sari, D. P., Febriani, O. M., \& Putra, A. S. (2018, November). Perancangan Sistem Informasi SDM Berprestasi pada SD Global Surya. In Prosiding Seminar Nasional Darmajaya (Vol. 1, No. 1, pp. 289-294).

Putra, A. S. (2018). Paperplain: Execution Fundamental Create Application With Borland Delphi 7.0 University Of Mitra Indonesia.

Putra, A. S., Sukri, H., \& Zuhri, K. Sistem Monitoring Realtime Jaringan Irigasi Desa (JIDES) Dengan Konsep Jaringan Sensor Nirkabel. IJEIS (Indonesian Journal of Electronics and Instrumentation Systems), 8(2), 221232.

Darmawan, A., Yuliawati, D. Marcella, O., \& Firmandala, R. (2016). Sistem Absensi dan Pelaporan Berbasis Fingerprint dan SMS Gateway. EXPLORE, 7(1).

Febriani, O. M., Wahyuni, T., \& Yusuf, S. (2017). DESIGN OF WEBSITE-BASED INFORMATION SYSTEM FOR EDOCUMENT ADMINISTRASI IN THE COMMUNITY SERVICE UNIT (A Case Study at Rajabasa District). 
INTERNATIONAL JOURNAL OF COMPUTERS \& TECHNOLOGY, 16(7), 7010-7020.

Febriani, O. M., \& Wahyuni, T. (2017, October). PERANCANGAN SISTEM E-DOCUMENT ADMINISTRASI LOGBOOK PENELITIAN PADA UNIT LAYANAN DI BANDAR LAMPUNG. In Prosiding Seminar Nasional Darmajaya (Vol. 1, No. 1, pp. 187-194).

Febriani, O. M., \& Permadi, A. B. (2017). Implementasi Sistem Aplikasi Data Bimbingan dan Pelanggaran Siswa pada Sekolah Menengah Atas di Lampung Tengah dengan Metode Analisis dan Desain Sistem Terdistribusi (SSAD). EXPERT, 7(1).

Febriani, O. M., \& Ambarwati, L. (2015). PERANCANGAN APLIKASI PENGOLAHAN DATA PENJUALAN UKM KELANTING KHAS TELO DESA SIDOHARJO KECAMATAN JATI AGUNG KABUPATEN LAMPUNG SELATAN. Jurnal Teknologi Informasi dan Bisnis Pengabdian Masyarakat Darmajaya, 1(1), 77-95.

Febriani, O. M. (2015). Rancang Bangun Aplikasi Ecommercemenggunakan Freewebstore pada UKM Kelanting di Desa Sidoharjo Lampung Selatan. Prosiding Sembistek 2014, 1(02), 446-458. 